EESTI NSV TEADUSTE AKADEEMIA TOIMETISED 1953. II k., nr. 3
ИЗВЕСТИЯ АКАДЕМИИ НАУК ЭСТОНСКОЯ ССР 1953. Том II, ㅅ 3

\title{
UURIMUSI VASTASTIKUSEST TOLMLEMISEST EESTI NSV-S LEVINUD VILJAPUUSORTIDEL
}

\author{
A. SIIMON, \\ põllumajandusteaduste doktor
}

NLKP XIX kongress seab kõigile põllumajanduse ala töötajaile suured ülesanded ka aianduse osas. Puuvilja- ja marjaaedade pindala suurendatakse viie aasta jooksul kolhoosides umbes $70 \%$ vorrra. Uute suuremate kolhoosi puuviljaaedade rajamisel, mis toimub piiratud arvu sortidega, tuleb tōsiselt arvestada kõiki tegureid, et aiad osutuksid viljakaiks. Oheks niisuguseks teguriks on sortide vastastikune tolmlemine.

I. V. Mitšurin (1) juhtis juba 1914. aastal tõsist tähelepanu sortide vastastikusele tolmlemisele ja hoiatas, et suuremate puuviljaaedade rajamisel peab aedades olema küllaldaselt tolmuandjaid sorte, tuues näite, kuidas 13000 puust koosnev Antonovka istandus osutus kõige parema agrotehnika juures peaaegu viljatuks.

Uute suuremate kolhoosi puuviljaaedade rajamisel piiratud arvu sortidega tuleb erilist rōhku panna sortide paigutusele aias, et nad oleksid vōimelised üksteist viljastama. Arvestades viljapuusortide vastastikuse tolmlemise suurt tähtsust saakide kindlustamisel, alustati 1945. aastal ka Eesti NSV-s viljapuusortide vastastikuse tolmlemise küsimuse uurimist. Kuigi mōnede siin esinevate sortide tolmlemise küsimust on mujal uuritud, on siinsed kohalikud tingimused siiski niivōrd erinevad, et nad ei jäta avaldamata mõju õiealgete diferentseerumisele ja seega ka õie üksikosade edasistele erifunktsioonidele, mille tõttu mujal saadud uurimistulemusi pole võimalik täiel määral kasutada. Käesolevas töös on uuritud sortide vastastikust tolmlemist peamiselt Eesti NSV standardsortimenti kuuluvatel sortidel, mil. ledele on ka leitud sobivad tolmuandjad isasordid.

\section{Oite viljastamisest viljapuudel}

Viljapuude juures toimub tolmuterade kandmine emakasuudmeile peaasjalikult mesilaste ning teiste putukate abil, kuna tuul etendab viljapuu tolmlemisel vähem tähtsat osa.

Tolmutera, sattudes mesilaste abil vôi muul teel ōie emakasuudme niiskesse miljöösse, eristab aineid, millel on regulatiivne môju tolmuterade idanemisele ja tolmuterade kasvamisele. Enne tolmuterade idanemist on tarvilik teatud keemilis-füüsikalise tasakaalu loomine sees- ja väljaspool tolmutera. Kui seda kriitilist seisukorda rikutakse väljaspool tolmutera liiga kõrge sekreedi kontsentratsiooniga, väheneb tolmuterade idanemine ning tolmuterade kasvamine. Samuti môjub halvavalt liigne niiskus, mis 
eemaldab tolmuteralt erituva vedeliku, mida vihmastel ōitseaegadel looduses sageli juhtub.

Kui emakasuudmele satub tolmuteri erisortidest, võib ühe sordi tolmuteradest erituv sekreet mōjuda teise sordi tolmuterade idanemisele soodustavalt ja vastupidi. Säärastes kombinatsioon-kultuurides etendab tähtsat osa ka sekreedi $\mathrm{pH}$ väärtus, kusjuures madalam $\mathrm{pH}$ mõjub takistavalt, kuna kõrgem $\mathrm{pH}$ avaldab soodsamat mōju tolmuterade idanemisele ja tolmuterade kasvatamisele. Oksikud uurijad, näit. Rjabov $\left({ }^{3}\right)$, on määranud tolmuteradest erituva sekreedi keemilist koosseisu ja jõudnud otsusele, et see sisaldab vees lahustuvaid fosfatiide, mis väljuvad tolmuteradest kohe kui viimased asetatakse vette, samuti annavad nad pärast vihma oksüdeerudes tolmuteradele pruuni värvi.

Idanemisega kaovad lahuses fosfatiidid, ning juba tolmutorude kasvamise alguseks on nad peaaegu täiesti kadunud.

Ollakse arvamusel, et fosfatiidid tarvitatakse kasvavate tolmutorude poolt ainevahetusel ära. Peale fosfatiidide on tolmuteras märgatud ka diastaasi, kuna kaltsiumi ja magneesiumi ühenditest polnud märgata mingisugust jälge.

Uldiselt on tolmuterades sisalduvad ained tugevasti pindaktiivsed ja tugevasti redutseerivad, mis on tingitud fosfatiididest. Enne idanemist on kalduvus $\mathrm{pH}$ suhtes leelisusele ja idanemise algusel langeb $\mathrm{pH}$ väärtus, tolmuterade kasvamisega aga algab kalduvus happesusele.

Tähtsam kui tolmuteradest erituv vedelik on tolmuterade idanemisel emakasuudmelt erituv eritus, mille keemilise koosseisu kohta on andmed väga erinevad. Nii pandi tähele, et Corydallese juures on emakasuudmel olev vedelik vahasarnane. Mikrokeemilised uurimised tõestasid, et emakasuue üldse ei erita suhkrut, vaid õlitaolist emulsiooni, mida leidub ka tolmuterades; sellel pole aga tolmuterade idanemise ja tolmutoru kasvamise suhtes mingisugust tähtsust. Osa autoreid arvab, et emakasuudmelt ja emakakaelast erituv vedelik sisaldab vees lahustuvaid fosfatiide ja letsitiine, ei sisalda aga suhkrut, valke, kaltsiumi, kaaliumi ja magneesiumi soolasid. Erituv vedelik mōjub redutseerivalt ja on pindaktiivne. Oksikud autorid jōudsid otsusele, et rasv on tähtsam osa sekreedist, kuid seal leidub ka suhkrut. Samuti ollakse arvamusel, et on ka olemas vahe emakasuudme ja emakakaela sekreedi vahel ja et emakakaelast erituvast vedelikust oleneb väga tunduvalt tolmutorude kasvamistugevus. Emakasuudme papillides on väga palju parkainet, emakakael on aga viimasest vaba. Ka emakasuudmel erituva sekreedi $\mathrm{pH}$ väärtus on tähtsaks teguriks tolmuterade idanemisel, kus madal $\mathrm{pH}$ väärtus mõjub takistavalt, kuna kõrgem $\mathrm{pH}$ väärtus mōjub soodustavalt.

Viljapuude erisortide ōitel on emakakael väga erineva pikkusega, mis omab tähtsust tolmuterade tungimisel munarakuni ja tolmu kandmisel mesilaste poolt.

Mõōtmised, mis teostati õunapuude juures Eesti NSV Teaduste Akadeemia Taimekasvatuse Instituudi Polli filiaali Morna aiamajandis, näitavad, et eri sortidel on emakakael kōrgemal tolmukatest (millimeetrites): Valge Astrahan - 5,0; Roheline klaarõun, Persikpunane suviõun ja Leedu pepin - 4,5; Antonovka ja Valge klaarōun - 4,0; Signe Tillisch 3,0 ; Säfstaholm ja Seerinka - 2,7; Nietschneri maasikõun $-2,5$; Borovinka ja Sügisjoonik - 2,0; Okerö - 1,9; Filippa - 1,8; Wealthy - 1,5; Pärnu tuviōun - 1,4; Liivi sibulõun - 0,9 ; Boiken $-0,7$; Paide taliõun $-0,5$; Croncels ja Martsipan - 0,4. Sortidel Lord Suffield, Suislepp ja Fameuse on emakas ja tolmukad ühekõrgusel; sortidel Tšernogus, Vaarikõun, Hea talupoeg ja Tallinna pirnōun on emakas õge vähe madalamal tolmukast. 
Seega tolmutera idanemisel ja tolmutoru kasvamisel ning selle tungimisel munarakuni on tegemist komplitseeritud biokeemiliste ja füüsikaliste tegurite kompleksiga. Emakasuudmest, kaelast ja tolmuterast erituv vedelik môjub eri sortide tolmutoru kasvule soodsalt või takistavalt ning muudab tolmusegudes oma õietolmu täiesti viljastusvõimeliseks [I. V. Mitšurin, (1) H. V. Turbin $\left.\left(^{5}\right)\right]$.

\section{Katsed kunstliku tolmlemise alal}

Kunstliku tolmlemise katseid korraldati viljapuude juures mille vanus kōikus $10-40$ aasta vahel. Vanemas eas (üle 40 aasta), nagu tõendavad tähelepanekud, muutuvad viljapuud hoopis isefertiilsemaks. Ka pöörati tähelepanu viljapuu tervislikule seisundile, korraldades katseid ainult nende puudega, mille tervislik seisukord osutus heaks ehk vähemalt rahuldavaks ning mis ei kannatanud alatoitluse all. Oied, mis isoleeriti, valiti oksalt, millele oli vōimalik marlikotte otsa siduda ja kus 3-4 õit asus lähestikku. Oite isoleerimisega alustati siis, kui kroonlehed ei olnud veel täiesti avanenud. Samuti olid ka tolmukotid veel avanemata.

Isoleeritud öied on füsioloogiliselt asetatud halvemasse seisukorda kui läheduses olevad katmata õied. Sageli langevad nad juba enneaegselt, sest viljapuu ei jõua oma toitetagavaradega kõiki õisi viljaks kasvatada ning maha langevad need õied, millel on halvemad elutingimused. Võiks isegi arvata, et isoleeritud õite läheduses olevad katmata ōied, omades juba alguses paremaid kasvutingimusi, arenevad kiiresti ning juhivad isegi toiteainete liikumissuunda isoleeritud õitelt katmata õitele. Kirjeldatud hädaohu kōrvaldamiseks ja isoleeritud öitele soodsamate kasvutingimuste loomiseks kõrvaldati isoleeritud ōite lähedusest kōik teised ōied.

Tolmu ülekandmine toimus kolm kuni neli päeva pärast isoleerimist, missugusel ajavahemikul emakas muutus vastuvõttevōimeliseks. Tähelepanu pöörati ka soodsamale tolmlemisajale. Nagu eelmiste aastate katsed näitasid, ei erita emakasuue pärast löunat harilikult kuigi palju vedelikku, sellepärast osutub sel ajal tolmlemine sagedasti tagajärjetuks, eriti veel tuuliste kuivade ilmade puhul. Hoopis rohkem eritab emakasuue vedelikku enne löunat kella $6-12$, olenevalt ka ilmastikust.

Tolmlemiseks tarvitatava tolmu muretsemiseks lōigati vastavailt sortidelt üksikud oksad arenenud õitega, millel tolmukad polnud veel täiesti avanenud. Oksad asetati $18-20^{\circ} \mathrm{C}$ toatemperatuuri, vastava etiketiga varustatud veepudelitesse, kus nad tavaliselt avanesid juba järgmistel päevadel. Oite võtmisel tolmu saamiseks peeti eriti silmas ka ōie asukohta, sest eelmiste aastate uurimused ( $\left.{ }^{7}\right)$ tõendavad, et tolmuterade idanemisprotsent oleneb oksa asendist ja õie asukohast oksal. Arvestades nimetatud asjaolusid, võeti korraldatud katsete juures õied enamasti rikkalikumalt päikest saanud kohtadelt ja oksa keskkohast. Samuti jälgiti, et õied oleksid hästi arenenud ja ühtlases arenemisastmes, sest vanemail öitel väheneb tolmuterade idanemisprotsent ja nörgeneb nende vitaalsus.

Tolmu ülekandmine emakasuudmele toimus õunapuusortide juures, kus katsetamismaterjali oli rohkesti, sel teel, et kroonlehed suruti sōrmedega tagasi ja vabanenud tolmukate otstega kanti tolm otsekohe emakasuudmele, tolmeldes kõiki viit emakasuudme haru. Kirjeldatud tolmu ülekandmise viis osutus väga otstarbekohaseks, sest tolmukate otstega õrnalt puudutades emakasuuet ei ärrita see üleliiga ega vigasta mehaaniliselt, nagu seda tihti võib juhtuda kõva pintsliga kunstlikul tolmlemisel. Tolmu kandmine emaka suudmele toimus rikkalikult, nii et tolmuteri võis palja silmaga märgata emaka suudmel erituval vedelikul, mis oli kindlaks tõenduseks, et tolm oli korralikult üle kantud. 
Pirnidel ja luuviljalistel, kus katsetamismaterjali oli piiratud arvul, koguti vastava sordi avanemata tolmukapeakesi ja asetati need toatemperatuuri $\left(18-20^{\circ} \mathrm{C}\right)$, paberile, kuni nende avanemiseni. Siis asetati tolmuka pead katseklaasi. Tolm kanti üle emakasuudmele tolmuülekandmise pulgaga. Tolmu emakasuudmele jäämist kontrolliti luubi abil. Tolmutatud õied kaeti uuesti marlikotiga ja vabastati neist kaheksandal päeval pärast tolmlemist, sest siis ei ole emakas vōōrtolmule enam vastuvōtlik. Nagu uurimused tõendavad, ei toimu viljastumine mitte kohe, esimestel päevadel pärast tolmlemist. Kõrvaldades marlikotid liiga vara, looksime ôitele küll soodsamad arenemistingimused, kuid vōib juhtuda, et emakas on veel niivōrd värske, et vōimaldab võôral tolmul idaneda ja isegi viljastada, kui eelmine tolmlemine ei andnud tagajärgi.

\section{Noorte viljade enneaegse languse pōhjustest ja külgejäänud viljade arvestamisest}

Noorte viljade enneaegse languse pōhjused on huvitanud paljusid uurijaid. Oks rühm uurijaid (Paškevitš, Rjabov jt.) jõuab vaatlusandmete pōhjal järeldusele, et seemnelistel viljapuudel langevad esimesel langusperioodil viljastamata õied ja viljastamata noorvili. Juunis eemaldab viljapuu endast veel need viljad, mida ta enam edasi ei jõua toita. Uhtlastel toitmistingimustel langevad varem alati need viljad, mis on puudulikult viljastatud või pole üldse viljastatud.

Teine rühm uurijaid, kes on jälginud viljastatud ja viljaks arenenud kui ka viljastatud ning langenud öite seemnepungi, leiavad, et langenud öite seas leidub sääraseid, millel on $5-7$ viljastatud seemnepunga, kuna paljudel kasvavatel ōitel kōigub viljastatud seemnepungade arv kõigest $2-4$ vahel. Oma uurimistulemustes nad märgivad, et õie edasiarenemine toimub paralleelselt toitmisintensiivsusega. On aga vaieldav, kas edasiarenemine oleneb paremast toitumusest või on parem toitmine tingitud edasiarenemisest. Arvatavasti on siiski viimane seisukoht ōigem.

Selgema ülevaate saamiseks selle kohta, kuivõrd viljade varisemine oleneb viljastatud seemnepungade arvust, teostati vastavaid uurimusi sortide Borovinka ja Leedu pepini juures. Nimetatud sortide juures toimus seemnete hulga kindlaksmääramine külgejäänud ja varisenud viljadel ajavahemikus 18. juulist kuni 18. augustini. Võrdse kasvutugevusega okstele pandi nimetatud ajavahemikul alla linad, et oleks võimalik täpselt kindlaks määrata, millistelt okstelt vili on varisenud. Varisenud viljad lõigati katki 10. augustil ja määrati kindlaks seemnete arv, kuna külgejäänud viljadel toimus seemnete arvestamine kaheksa päeva hiljem, s. o. 18. augustil, et oleks vōimalik otsustada nende edaspidise arenemise üle. Andmed seemnete, varisenud ja külgejäänud viljade hulga kohta on toodud tabelis 1 .

Tabel 1 .

\begin{tabular}{l|c|c|c|c|c}
\hline \multicolumn{1}{c|}{ Sort } & $\begin{array}{c}\text { Viljapuu } \\
\text { number }\end{array}$ & $\begin{array}{c}\text { Varisenud } \\
\text { viljade arv }\end{array}$ & $\begin{array}{c}\text { Keskmine seemnete } \\
\text { arv varisenud } \\
\text { viljades }\end{array}$ & $\begin{array}{c}\text { Viljapuult maha- } \\
\text { vôetud viljade } \\
\text { arv }\end{array}$ & $\begin{array}{c}\text { Keskmine seem- } \\
\text { nete arv maha- } \\
\text { võetud viljades }\end{array}$ \\
\hline \multirow{3}{*}{$\begin{array}{l}\text { Borovinka } \\
\text { Leedu pepin }\end{array}$} & 297 & 64 & 6,9 & 64 & 7,4 \\
\hline
\end{tabular}

Toodud andmetest nähtub, et sort Borovinkal on seemnete arv külgejäänud viljadel 0,5 seemne vōrra suurem kui varisenud viljadel, kuid varisenud 
viljade hulgas leidus ka üksikuid vilju, mille seemnete arv oli suurem kui külgejäänud viljadel. Leedu pepinil on keskmine seemnete arv varisenud vil. jades isegi 0,2 vörra vilja kohta suurem kui külgejäänud viljadel. Sellest selgub, et enneaegne viljade varisemine ei ole tingitud mitte viljastatud seemnepungade arvust, vaid varisemise pōhjuseid tuleb otsida mujalt.

Et maha langeb ka osa sääraseid õisi, milledel seemnepungad on viljastatud, siis tuleb sellele vaadata kui loomulikule nähtusele, sest viljapuu ei jōua kõiki temal olevaid vilju toita.

Pōhjust, miks viljad väiksema viljastatud seemnepungade arvuga sageli vōivad jääda kasvama ning edasi areneda, tuleb otsida kindlasti toitmistingimuste erinevusest viljapuu üksikutel okstel. Nagu autori poolt teos. tatud uurimused tõendavad, oleneb viljapuu õite üksikute osade arenemine tunduval määral ka õite asupaigast oksal.

Oied, mis asuvad tugevamatel okstel ja päikeserikkamatel kohtadel, toituvad juba alguses paremini, arenevad kiiresti ja vōtavad toitu isegi teistelt õitelt, mispärast viimased langevad, olgugi et neil on suurem arv viljastatud seemnepungi. Mida suuremad erinevused on viljastamise protsessis ühinenud sugurakkude vahel, seda suurem on ka organismi elujōulisuse aste; ühinevate suguelementide vastuolud ongi areneva organismi elujōulisuse füsioloogiliseks aluseks.

Uhenduses noorte viljade mahalangemisega on oluline ka külgejäänud noorte viljade hulga kindlaksmääramine, mis peab tõendama sortide vastastikust viljastamisvõimet. Oma katsetel alustas autor külgejäänud noorte viljade kindlaksmääramist 42. päeval pärast tolmlemist, sest selleks ajaks oli viljastamata jäänud ning nõrgasti viljastatud vili juba maha langenud. Samuti oli sel ajal juba võimalik otsustada ühe vôi teise vilja edasise arenemiskäigu üle. Teistkordne hinnang külgejäänud viljade kohta toimus vilja valmimise järgus, kus lähemalt jälgiti eri isasortide mōju vilja arengule.

Sortide isesteriilsuse kohta selgusele jõudmiseks määrati oma sordi õietolmuga tolmeldud õitel külgejäänud noor vili samuti 42. päeval pärast tolmlemist. Ohtlasi jälgiti valminud viljadel arenenud seemnete hulka. Olgugi, et seemneviljalistel on partenokarpia kaunis haruldane nähe, osutus sortide isesteriilsuse kindlaksmääramisel tarvilikuks arenenud seemnete jälgimine.

\section{Kunstliku tolmlemise katsed õunapuudega}

Kunstliku tolmlemise katsed paremate isasortide väljaselgitamiseks Eesti NSV-s enamlevinud õunapuusortidele toimusid 1945. aastast 1952. aastani Eesti NSV Teaduste Akadeemia taimekasvatuse Instituudi Polli filiaalis, kus oli võimalik kasutada rikkalikku katsetamismaterjali, mis kasvas tugevakasvulistel alustel ja ühtlastes agrotehnilistes tingimustes. Katsetulemused on toodud tabelis 2 .

Toodud tabelit jälgides näeme, et enamikul sortidest arenesid oma tolmuga viljastatud ōitest väga vähesed viljaks ning külgejäänud noorte viljade protsent on madal. Suurem osa langes enneaegselt, Korralikuks viljastamiseks vajavad nad võõra sordi õietolmu. Need sordid osutusid praktiliselt isesteriilseks. Praktilise isesteriilsuse mõiste on puuviljakasvatajate seas väga levinud ja seda terminit kasutatakse ka käesolevas kirjutuses. Praktiliselt isesteriilseiks nimetame sorte, mis oma öietolmuga kunstlikul tolmlemisel annavad teatud tulemusi, kuid mitte niisugusel määral, et see kindlustaks rikkaliku saagi. Viimase kindlustamiseks tuleks kasutada võõra sordi õietolmu. 
Normaalseit arenenud noorte viljade arv

(protsentides, kolme aasta keskmisena)

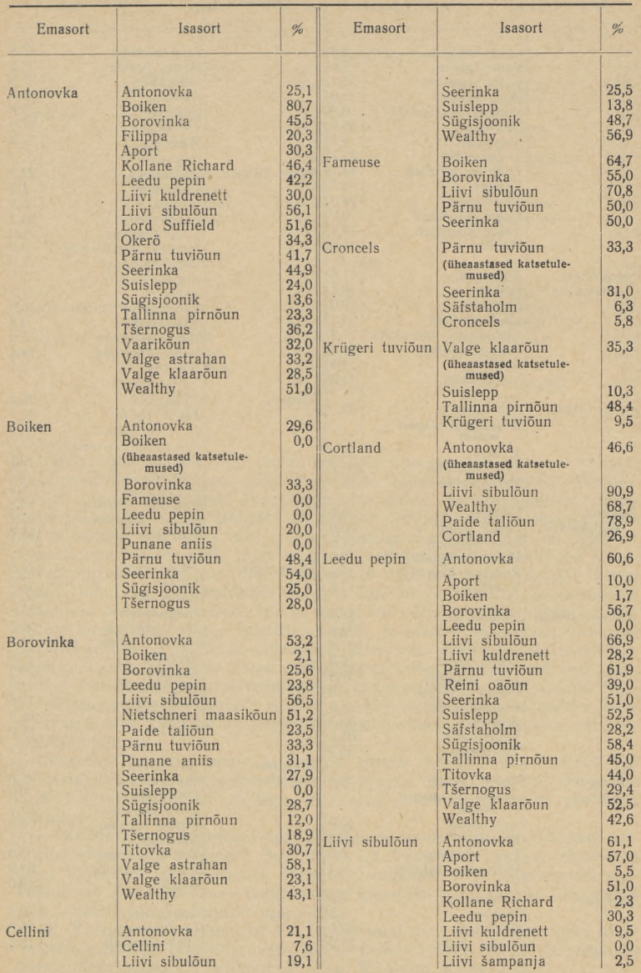




\begin{tabular}{|c|c|c|c|c|c|}
\hline Emasort & Isasort & $\%$ & Emasort & Isasort & $\%$ \\
\hline $\begin{array}{l}\text { Nietschneri } \\
\text { maasikőun }\end{array}$ & $\begin{array}{l}\text { Lord Suffield } \\
\text { Paide taliōun } \\
\text { Pärnu tuviōun } \\
\text { Punane aniis } \\
\text { Punane sügiskalvill } \\
\text { Seerinka } \\
\text { Suislepp } \\
\text { Sügisjoonik } \\
\text { Tallinna pirnôun } \\
\text { Titovka } \\
\text { TŚernogus } \\
\text { Valge Astrahan } \\
\text { Valge klaarōun } \\
\text { Wealthy } \\
\\
\text { Antonovka } \\
\text { Boiken } \\
\text { Fameuse } \\
\text { Liivi sibulōun } \\
\text { Nietschneri maasikõun } \\
\text { Pärnu tuviōun } \\
\text { Seerinka } \\
\text { Sügisjoonik }\end{array}$ & $\begin{array}{r}6,8 \\
5,0 \\
50,1 \\
0,0 \\
0,0 \\
55,1 \\
4,5 \\
35,7 \\
44,7 \\
5,3 \\
24,3 \\
0,0 \\
12,1 \\
13,6 \\
\\
37,6 \\
46,1 \\
59,0 \\
54,2 \\
18,8 \\
50,6 \\
54,8 \\
33,6 \\
\end{array}$ & Signe Tillisch & $\begin{array}{l}\text { Liivi sibulōun } \\
\text { Părnu tuviōun } \\
\text { Seerinka } \\
\text { Suislepp } \\
\text { Sügisjoonik } \\
\text { TŠernogus } \\
\text { Wealthy } \\
\text { Antonovka } \\
\text { Borovinka } \\
\text { Filippa } \\
\text { Leedu pepin } \\
\text { Liivi sibulōun } \\
\text { Punane sügiskalvill } \\
\text { Roheline klaar } \\
\text { Signe Tillisch } \\
\text { Suislepp } \\
\text { Tallinna pirnōun } \\
\text { Vaarikōun } \\
\text { Valge astrahan } \\
\text { Valge klaarōun } \\
\text { Wealthy }\end{array}$ & $\begin{array}{r}37,8 \\
33,1 \\
32,6 \\
20,9 \\
52,8 \\
23,9 \\
47,8 \\
\\
22,9 \\
1,8 \\
5,5 \\
34,2 \\
28,0 \\
0,0 \\
24,0 \\
1,7 \\
1,7 \\
0,0 \\
2,8 \\
5,0 \\
14,4 \\
2,1\end{array}$ \\
\hline Paide taliōun & 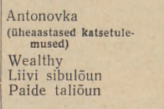 & $\begin{array}{l}58,3 \\
22,7 \\
10,2\end{array}$ & Suislepp & $\begin{array}{l}\text { Antonovka } \\
\text { Leedu pepin } \\
\text { Liivi sibulōun } \\
\text { Nietschneri maasikôun } \\
\text { Seerinka } \\
\text { Suislepp } \\
\text { Sügisjoonik }\end{array}$ & $\begin{array}{r}25,1 \\
21,7 \\
25,9 \\
48,0 \\
40,7 \\
5,2 \\
31,7\end{array}$ \\
\hline $\begin{array}{l}\text { Punane } \\
\text { sügiskalvill }\end{array}$ & $\begin{array}{l}\text { Filippa } \\
\text { Leedu pepin } \\
\text { Liivi sibulōun } \\
\text { Punane sügiskalvill } \\
\text { Roheline klaarōun } \\
\text { Vaarikōun }\end{array}$ & $\begin{array}{r}7,6 \\
10,0 \\
11,6 \\
0,0 \\
15,4 \\
11,6\end{array}$ & Sügisjoonik & $\begin{array}{l}\text { Tallinna pirnōun } \\
\text { Valge klaarōun } \\
\text { Wealthy } \\
\text { Antonovka } \\
\text { Boiken } \\
\text { Borovinka }\end{array}$ & $\begin{array}{r}13,5 \\
47,8 \\
22,4 \\
\\
34,4 \\
7,5 \\
55,6\end{array}$ \\
\hline Pärnu tuviōun & $\begin{array}{l}\text { Antonovka } \\
\text { Boiken } \\
\text { Borovinka } \\
\text { Leedu pepin } \\
\text { Liivi sibulōun } \\
\text { Pärnu tuviōun } \\
\text { Punane anïs } \\
\text { Seerinka } \\
\text { Sügisjoonik } \\
\text { Tšernogus }\end{array}$ & $\begin{array}{r}50,6 \\
23,5 \\
21,6 \\
10,0 \\
37,5 \\
6,5 \\
7,9 \\
32,3 \\
35,0 \\
56,9\end{array}$ & & $\begin{array}{l}\text { Leedu pepin } \\
\text { Liivi sibulōun } \\
\text { Pärnu tuviōun } \\
\text { Seerinka } \\
\text { Suislepp } \\
\text { Sügisjoonik } \\
\text { TŠernogus } \\
\text { Valge klaar } \\
\text { Wealthy }\end{array}$ & $\begin{array}{l}35,5 \\
30,5 \\
71,3 \\
24,0 \\
29,2 \\
41,6 \\
15,5 \\
55,4 \\
56,7\end{array}$ \\
\hline $\begin{array}{c}\text { Pōltsamaa } \\
\text { taliōun }\end{array}$ & $\begin{array}{l}\begin{array}{l}\text { Paide taliōun } \\
\text { (üheaastased katsetule- } \\
\text { mused) }\end{array} \\
\text { Antonovka } \\
\text { Wealthy } \\
\text { Liivi sibulōun } \\
\text { Põltsamaa taliōun }\end{array}$ & $\begin{array}{r}40,0 \\
42,8 \\
0,0 \\
8,4\end{array}$ & $\begin{array}{l}\text { Tallinna } \\
\text { pirnōun }\end{array}$ & $\begin{array}{l}\text { Antonovka } \\
\text { Borovinka } \\
\text { Leedu pepin } \\
\text { Liivi sibulōun } \\
\text { Pärnu tuviōun } \\
\text { Suislepp } \\
\text { Tallinna pirnōun } \\
\text { Valge klaarōun } \\
\text { Wealthy }\end{array}$ & $\begin{array}{r}6,7 \\
35,0 \\
9,4 \\
52,9 \\
6,9 \\
12,1 \\
0,0 \\
34,9 \\
19,0\end{array}$ \\
\hline Seerinka & $\begin{array}{l}\text { Antonovka } \\
\text { Boiken } \\
\text { Borovinka } \\
\text { Leedu pepin }\end{array}$ & $\begin{array}{r}8,6 \\
4,5 \\
33,0 \\
15,6\end{array}$ & Titovka & $\begin{array}{l}\text { Antonovka } \\
\text { Leedu pepin } \\
\text { Liivi sibulōun }\end{array}$ & $\begin{array}{r}9,7 \\
15,0 \\
13,2\end{array}$ \\
\hline
\end{tabular}




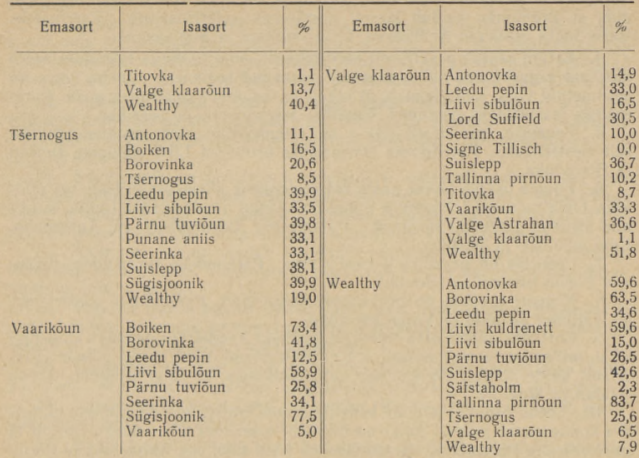

Isefertiilsus või õigemini kalduvus isefertiilsusele on meil esinevatel õunapuusortidel haruldane nähe, kuid siiski võime seda märgata üksikute sortide juures soodsamate kasvutingimuste puhul. Sortidevaheliste tolmlemiste tulemustes vōime märgata eri aastatel teatud kōikumisi, mis on tingitud mitmetest muutlikest sise- kui ka välisteguritest, sest siin on tegemist tolmuteraga, mis on rakk, mille plasma keemilised, kolloidkeemilised ja teised omadused võivad muutlike välistegurite tōttu muutuda. Viimaste toimel võivad muutuda nii ensüümide tegevus kui ka rakuplasma biokeemilised omadused. Samasugust mõju võivad muutlikud välistegurid avaldada ka arenevale munarakule. Kuigi muutlikud välis- ja sisetegurid võivad üksikutel aastatel sortide vastastikuse tolmlemise tulemustes esile kutsuda teatud kōi. kumisi, ei kutsu nad esile täiesti uusi erinevusi vahekordades, vaid need vahekorrad sortide vastastikuses tolmlemises avalduvad siiski kindlal kujul (teatud kōikumistega igal aastal). Sordid, mis ühel aastal andsid tolmeldes paremaid tagajärgi, osutusid ka järgmistel aastatel teatud sordi suhtes paremateks tolmlejateks.

Selgema ülevaate saamiseks levinud sortide isesteriilsusc, isefertiilsuse ja vastastikuse viljastusvőime kohta on allpool üksikult toodud emasordid koos kolme isasordiga, millega kunstlikul tolmlemisel saadi paremaid tulemusi.

1. Antonovka - tolmeldes oma õietolmuga andis vilja, mis sisaldas normaalselt arenenud seemneid. See näitab, et Antonovka avaldab võrdlemisi suurt kalduvust isefertiilsusele. Paremaid tulemusi võib viljastamisel saavutada kui Antonovka oma tolmu asemel kasutada tolmlemiseks Liivi sibulõuna, Wealthy ja Seerinka tolmu.

2. Boiken, mis on Eesti NSV-s vähelevinud sort, osutus kunstlikul tolmlemisel, mis viidi läbi ühe aasta vältel, täiesti isesteriilseks. Paremateks tolmlejateks temale on Antonovka, Valge klaarõun ja Seerinka. 
3. Borovinka on kunstlikel tolmlemiskatsetel andnud oma öietolmuga normaalselt arenenud vilju, mille keskmine seemnete arv oli 5,5 . See tōendab, et Borovinka kaldub kõrgel agrofoonil isefertiilsusele. Paremateks isasortideks osutuvad Antonovka, Liivi sibulōun ja Sügisjoonik.

4. Cellini osutub praktiliselt isesteriilseks, oma tolmuga tolmeldes saadi üksikuid vilju, milles oli normaalselt arenenud seemneid. Leidus aga ka seemnetuid vilju, mis tōendab, et sordil on kalduvus partenokarpiale. Paremateks isasortideks osutuvad Wealthy, Sügisjoonik ja Seerinka.

5. Fameuse, mis Eesti NSV-s on vähelevinud sort, osutus praktiliselt isesteriilseks. Paremateks isasortideks osutuvad Liivi sibulöun, Boiken ja Borovinka.

6. Filippa osutub kolme aasta katsetulemuste alusel praktiliselt isesteriilseks. Oma tolmuga tolmlemise puhul on saadud ainult üksikuid vilju, milles olid üksikud arenenud seemned. Paremateks isasortideks on Antonovka, Liivi sibulõun ja Wealthy.

7. Croncels on praktiliselt isesteriilne. Paremateks isasortideks osutuvad Pärnu tuviõun ja Seerinka.

8. Krügeri tuviôun on praktiliselt isesteriilne. Paremateks isasortideks on Tallinna pirnõun ja Valge klaarõun.

9. Cortland annab oma tolmuga üksikuid kaunis normaalselt arenenud vilju, milles on ka normaalselt arenenud seemned. Sorti tuleks pidada praktiliselt isesteriilseks. Paremateks tolmuandjateks on Liivi sibulõun, Paide taliõun ja Wealthy.

10. Leedu pepin ei andnud kunstlikul tolmlemisel oma öietolmuga tolmeldes kolme aasta jooksul ühtki normaalselt arenenud vilja. Seega osutub ta isesteriilseks. Paremateks isasortideks on Liivi sibulounn, Antonovka ja Pärnu tuviõun.

11. Liivi sibulōun andis kunstlikul tolmlemisel oma õietolmuga kolme aasta jooksul ainult üksikuid vilju, milles olid üksikud arenenud seemned. Seega osutus ta praktiliselt isesteriilseks. Paremateks isasortideks on Antonovka, Seerinka, Borovinka ja Aport.

12. Nietschneri maasikõun andis oma ōietolmuga tolmeldes vilju, millest iga vili sisaldas keskmiselt 5 arenenud seemet. Seega on sordil kalduvus isefertiilsusele, kuid tolmeldes võōra sordi õietolmuga saadakse paremaid tulemusi. Paremateks isasortideks on Seerinka, Pärnu tuviōun ja Liivi sibulõun.

13. Paide taliōun on praktiliselt isesteriilne, oma ōietolmuga tolmeldes annab ta normaalselt arenenud vilja, milles on ka arenenud seemned, kuid viljastub palju rikkalikumalt, kui isasortideks kasutada Wealthyt ja Antonovkat. Isegi Liivi sibulōuna tolm annab siin soodsaid tulemusi.

14. Punane sügiskalvill osutub kolme aasta jooksul teostatud kunstliku tolmlemise tulemuste alusel isesteriilseks. Oma tolmuga tolmeldes ei arenenud kolme aasta jooksul ainustki vilja. Paremateks isasortideks on Livi sibulōun, Leedu pepin ja Vaarikõun.

15. Pärnu tuviõun on oma õietolmuga tolmeldes kolme aasta jooksul andnud arenenud vilju, mis sisaldavad keskmiselt 7,2 seemet. Seega avaldab Pärnu tuviōun suurt kalduvust isefertiilsusele. Teisteks sortideks mis Pärnu tuviõunaga tolmeldes andsid häid tulemusi, on Antono .a., Tšernogus ja Liivi sibulōun ning sügissortidest Sügisjoonik ja Seerinka.

16. Pōltsamaa taliōun on ühe aasta katsetulemuste pōhjal praktiliselt isesteriilne. Paremateks isasortideks on Wealthy, Antonovka ja Paide talioun.

17. Seerinka andis oma öietolmuga tolmeldes kolmel aastal vilju, millest iga vili sisaldas keskmiselt 5 seemet, näidates sellega suurt kalduvust 
isefertiilsusele. Paremateks isasortideks on Sügisjoonik, Wealthy ja Liivi sibulōun.

18. Signe Tillisch osutub isesteriilseks. Olgugi et kolme aasta jooksul saadi oma öietolmuga tolmlemisel üksikuid vilju, olid nad seemnetud või vähe arenenud seemnetega, mis näitab kalduvust partenokarpiale. Paremad isasordid on Liivimaa sibulōun, Leedu pepin, Antonovka ja Roheline klaar.

19. Suisleppa tuleks pidada peaaegu isesteriilseks. Olgugi et oma ōietolmuga tolmeldes saadi üksikuid vilju, olid nende seemned vähe arenenud. Paremateks isasortideks on Valge klaarōun, Seerinka, Nietschneri maasikõun ja Liivi sibulõun.

20. Sügisjoonik on praktiliselt isesteriilne, üksikuil aastail saadi oma tolmuga tolmeldes vilju, mis sisaldasid keskmiselt 3,2 seemet, kuna mõnel aastal ei anna ta oma õietolmuga tolmeldes mingisuguseid tulemusi. Paremateks isasortideks on Pärnu tuviốun, Wealthy ja Valge klaarõun.

21. Tallinna pirnõun osutub kunstliku tolmlemise puhul oma tolmuga tolmeldes isesteriilseks. Paremateks isasortideks on Valge klaarōun, Borovinka ja Liivi sibulōun.

22. Titovkat tuleks pidada isesteriilseks, sest oma tolmuga tolmeldes ei saadud ühtegi arenenud seemnetega vilja. Paremateks isasortideks osutuvad Wealthy, Liivi sibulōun ja Valge klaarōun.

23. Tšernogus on praktiliselt isesteriilne. Paremateks isasortideks osutuvad Leedu pepin, Pärnu tuviõun, Sügisjoonik, Liivi sibulōun ja Suislepp.

24. Vaarikõun on praktiliselt isesteriilne. Paremateks isasortideks osutuvad Sügisjoonik, Liivi sibulõun ja Boiken.

25. Valge klaarõun andis oma õietolmuga tolmeldes üksikuil aastatel normaalselt arenenud vilju, mis sisaldasid normaalselt arenenud seemneid, kuid järgmistel aastatel ei arenenud oma tolmuga tolmelnud ōitest ainustki vilja. Seega tuleks Valget klaarõuna pidada praktiliselt isesteriilseks. Paremateks isasortideks on Wealthy ja Suislepp.

26. Wealthy on praktiliselt isesteriilne. Paremateks isasortideks on Antonovka, Borovinka, Liivi kuldrenett ja Tallinna pirnōun.

Kui jälgida kunstlikul tolmlemisel kasutatud üksikuid isasorte, siis näeme, et nende viljastamisvōime on väga erinev. Ohed neist on võimelised tagajärjekalt viljastama suurt arvu emasorte, kuna teised aga annavad soovitud tulemusi ainult üksikute emasortidega. Näitena olgu siin toodud sordid Borovinka ja Liivi sibulōun, mida kunstlikul tolmlemisel on kasutatud isasortidena 7 emasordi juures (Antonovka, Leedu pepin, Signe Tillisch, Sügisjoonik, Tallinna pirnōun, Tšernogus ja Wealthy). Liivi sibulōun andis tolmeldes paremaid tulemusi 5 emasordiga (Antonovka, Filippa, Leedu pepin, Signe Tillisch, Tallinna pirnõun, Tšernogus). Ainult kahe emasordi (Sügisjoonik ja Wealthy) puhul viljastab Borovinka paremini kui Liivi sibulōun. Sellest nähtub, et vastastikune tolmlemine annab soovitud tulemusi ainult teatud sortide vahel ja et see nähtus ilmneb igal aastal nõrgemal või tugevamal kujul, olenedes sise- ja välistegurite kompleksi mōju intensiivsusest.

\section{Kunstliku tolmlemise katsed pirnipuudega}

Andmed vastastikuse tolmlemise kohta on toodud tabelis 3 .

Pirnipuude sortide vastastikuse tolmlemise katsetulemustest selgus järgmist.

1. Liivi roheline võipirn, mis muidu on külmakindel, on teiste sortidega vōrreldes väga külmatundlike öitega, mis enamuses hävinevad igal aastal isegi öige nõrga hiliskevadise külma puhul. Sort on peaaegu isesteriilne, oma tol- 
Normaalselt arenenud noorte viljade arv (protsentides, kolme aasta keskmisena)

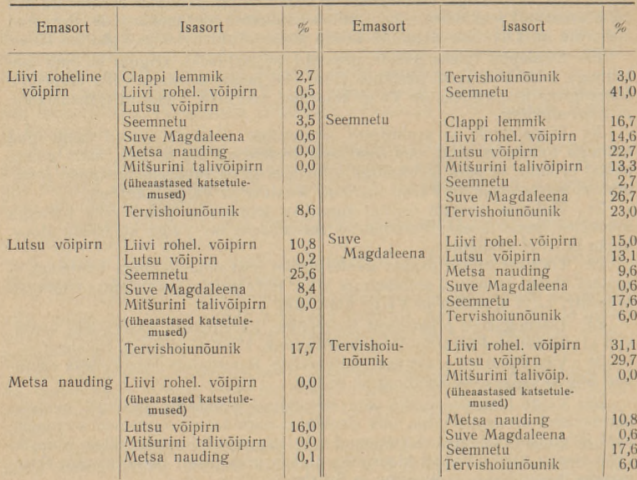

muga tolmeldes oli külgejäänud viljasid tolmutatud õite arvust kōigest $0,5 \%$. Paremateks tolmlejateks on Tervishoiunõunik ja Seemnetu.

2. Lutsu võipirn on praktiliselt isesteriilne. Paremateks isasortideks osutuvad Seemnetu ja Tervishoiunōunik.

3. Metsa naudingu kohta on olemas ainult üheaastased andmed, mille alusel ta osutus peaagu isesteriilseks. Paremateks tolmlejateks osutuvad Seemnetu ja Lutsu vōipirn.

4. Sort Seemnetu on praktiliselt isesteriilne, oma tolmuga tolmeldes oli külgejäänud viljasid tolmutatud öite arvust $2,7 \%$. Paremateks isasortideks osutuvad Suve Magdaleena ja Tervishoiunõunik.

5. Suve Magdaleena on praktiliselt isesteriilne. Paremateks isasortideks on Seemnetu, Liivi roheline vôipirn ja Lutsu vôipirn.

6. Tervishoiunōunik on praktiliselt isesteriilne, oma tolmuga tolmeldes oli külgejäänud viljasid tolmutatud öite arvust $6 \%$. Paremateks isasortideks osutuvad Liivi roheline võipirn, Lutsu võipirn ja Seemnetu.

\section{Kunstliku tolmlemise katsed kirsipuudega}

Kirsisortide vastastikuse tolmlemise uurimiseks võeti emasortideks 9 levinumat sorti, millede kohta uurimistulemused vastastikusest tolmlemisest on toodud tabelis 4 .

Toodud tabelist selgub, et kirsisortide vastastikuse tolmlemise küsimuste selgitamisel on võimalik teha järgmisi järeldusi. 
Külgejäänud viljade arv (protsentides öite arvust, kolme aasta keskmisena)

\begin{tabular}{|c|c|c|c|c|c|}
\hline Emasort & Isasort & $\%$ & Emasort & Isasort & $\%$ \\
\hline $\begin{array}{l}\text { Punane } \\
\text { viljakas }\end{array}$ & $\begin{array}{l}\text { Kentkirss } \\
\text { Klaaskirss } \\
\text { Cassino varajane } \\
\text { Ostheimi veiksel } \\
\text { Punane viljakas } \\
\text { Punane maikirss } \\
\text { Podbielsky }\end{array}$ & $\begin{array}{r}40,4 \\
60,0 \\
22,5 \\
3,8 \\
0,0 \\
20,5 \\
0,8\end{array}$ & Klaaskirss & $\begin{array}{l}\text { Cassino varajane } \\
\text { Punane maikirss } \\
\text { Klaaskirss } \\
\text { Ostheimi veiksel } \\
\text { Kentkirss } \\
\text { Punane viljakas } \\
\text { Punane maikirss }\end{array}$ & $\begin{array}{r}42,2 \\
26,4 \\
5,5 \\
22,8 \\
20,0 \\
42,2 \\
4,2\end{array}$ \\
\hline Kentkirss & $\begin{array}{l}\text { Kentkirss } \\
\text { Podbielsky } \\
\text { Punane viljakas } \\
\text { Ostheimi veiksel } \\
\text { Klaaskirss } \\
\text { Cassino varajane } \\
\text { Punane maikirss }\end{array}$ & $\begin{array}{r}15,6 \\
6,6 \\
21,8 \\
29,9 \\
30,0 \\
31,4 \\
14,7\end{array}$ & $\begin{array}{l}\text { Cassino } \\
\text { varajane }\end{array}$ & $\begin{array}{l}\text { Cassino varajane } \\
\text { Kentkirss } \\
\text { Metsik hapukirss } \\
\text { Punane viljakas } \\
\text { Metsik hapukirss } \\
\text { Punane viljakas }\end{array}$ & $\begin{array}{r}8,6 \\
0,0 \\
0,0 \\
34,0 \\
55,5 \\
34,9\end{array}$ \\
\hline Sâilisveiksel & $\begin{array}{l}\text { Säilisveiksel } \\
\text { Podbielsky } \\
\text { Kent } \\
\text { Punane viljakas } \\
\text { Ostheimi veiksel } \\
\text { (üheasstased katsetu- } \\
\quad \text { lemused) } \\
\text { Sirpotreb }\end{array}$ & $\begin{array}{r}32,1 \\
30,8 \\
25,4 \\
21,6 \\
0,0\end{array}$ & $\begin{array}{l}\text { Punane } \\
\text { maikirss }\end{array}$ & $\begin{array}{l}\text { Kentkirss } \\
\text { Metsik hapukirss } \\
\text { Punane viljakas } \\
\text { Cassino varajane } \\
\text { Kentkirss } \\
\text { (theaastased katsetu. } \\
\text { Iemused) }\end{array}$ & $\begin{array}{r}0,0 \\
23,8 \\
10,3 \\
3,2 \\
16,6\end{array}$ \\
\hline $\begin{array}{l}\text { Ostheimi } \\
\text { veiksel }\end{array}$ & $\begin{array}{l}\text { Ostheimi veiksel } \\
\text { Klaaskirss } \\
\text { Kentkirss } \\
\text { Punane viljakas }\end{array}$ & $\begin{array}{r}0,4 \\
51,2 \\
31,4 \\
2,3\end{array}$ & & $\begin{array}{l}\text { Punane viljakas } \\
\text { Ostheimi veiksel } \\
\text { Sáilisveiksel }\end{array}$ & $\begin{array}{l}51,3 \\
70,0 \\
28,1\end{array}$ \\
\hline
\end{tabular}

1. Sort Punane viljakas on isesteriilne. Paremateks tolmlejateks temale osutuvad Kentkirss ja Klaaskirss.

2. Kentkirss on praktiliselt isesteriilne. Paremateks tolmlejateks temale on Ostheimi veiksel, Klaaskirss ja Punane viljakas.

3. Säilisveiksel on isefertiilne, oma tolmuga tolmeldes annab häid tulemusi.

4. Ostheimi veiksel on peaaegu isesteriilne. Paremateks tolmlejateks on Kentkirss ja Klaaskirss.

5. Klaaskirss on praktiliselt isesteriilne. Paremateks tolmlejateks osutuvad Punane viljakas ja Ostheimi veiksel.

6. Maguskirsil Cassino varajane on parimaks tolmlejaks Punane viljakas.

7. Diemetzi amarellile on paremateks tolmlejateks Punane viljakas ja Metsik maguskirss.

8. Punasel maikirsil on paremateks tolmlejateks Punane viljakas ja Metsik maguskirss.

\section{Kunstliku tolmlemise katsed ploomipuudega}

Ploomisortide vastastikuse tolmlemise uurimiseks võeti 15 enamlevinud sorti, milledele selgitati paremad tolmuandjad. Uurimistulemused on toodud tabelis 5 .

Toodud tabeli alusel on võimalik sortide vastastikusest tolmlemisest teha järgmisi järeldusi. 
Tabel 5

Külgejäänud viljade arv (protsentides tolmutatud õite arvust, kolme aasta keskmisena)

\begin{tabular}{l|l|l}
\hline Emasort & Isasort \\
\hline
\end{tabular}

Emma Leppermann

Emma Leppermann

48,8

Wilhelmine Späth

25,8

Varajane sinine

58,6

Edinburgi ploom

Althani renklood

70,0

Roheline renklood

40,7

Wangenheimi säilisploom

48,8

Liivi kollane munaploom

62,5

Liivi kollane munaploom

Wilhelmine Späth

Varajane sinine

Emma Leppermann

Varajane punane

Edinburgi ploom

Späthi varajane

Althani renklood

Wangenheimi säilisploom

0,0

26,1

13,6

57,6

65,8

57,8

68,3

43,2

Roheline renklood

37,2

41,1

Varajane sinine

Emma Leppermann

Althani renklood

Edinburgi ploom

33,9

41,3

44,2

Edinburgi ploom

Varajane sinine

Wilhelmine Späth

Emma Leppermann

89,5

100,0

55,5

Wangenheimi säilisploom

Wangenheimi säilisploom

45,8

Edinburgi ploom

Wilhelmine Späth

Emma Leppermann

Varajane punane

Althani renklood

Oullinsi renklood

Emma Leppermann

Varajane punane

Späthi varajane

Edinburgi ploom

Varajane sinine

Althani renklood

Edinburgi ploom

Späthi varajane

Varajane punane

Emma Leppermann

Wilhelmine Späth

Varajane sinine

Wangenheimi săilisploom

Roheline renklood

45,2

35,5

36,5

5,7

45,3

12,4

2,0

15,6

19,7

55,1

28,2

28,6

30,3

17,8

16,1

16,0

34,7

17,1

Wilhelmine Späth

Wilhelmine Späth

Varajane sinine

Emma Leppermann

Varajane punane

(thiheastased andmed)

Emma Leppermann

Varajane punane

Späthi varajane

Emma Leppermann

Edinburgi ploom

Varajane sinine

Althani renklood 


\begin{tabular}{|c|c|c|}
\hline Emasort & Isasort & $\%$ \\
\hline Suur roheline & $\begin{array}{l}\text { Späthi varajane } \\
\text { Edinburgi ploom } \\
\text { Emma Leppermann } \\
\text { Varajane sinine }\end{array}$ & $\begin{array}{r}5,1 \\
12,0 \\
7,2 \\
25,0\end{array}$ \\
\hline Ruth Gerstetter & $\begin{array}{l}\text { Wilhelmine Späth } \\
\text { Edinburgi ploom } \\
\text { Varajane sinine } \\
\text { Emma Leppermann }\end{array}$ & $\begin{array}{l}40,0 \\
37,4 \\
50,0 \\
40,0\end{array}$ \\
\hline Suur kollane munaploom & $\begin{array}{l}\text { Wilhelmine Späth } \\
\text { Emma Leppermann } \\
\text { Edinburgi ploom } \\
\text { Varajane sinine }\end{array}$ & $\begin{array}{l}73,8 \\
75,0 \\
50,0 \\
69,3\end{array}$ \\
\hline
\end{tabular}

1. Sort Emma Leppermann on kalduv isefertiilsusele, kuid paremateks isasortideks osutuvad Varajane sinine, Wangenheimi säilisploom ja Edinburgi ploom.

2. Liivi kollane munaploom on isesteriilne. Paremateks tolmlejateks osutuvad Emma Leppermann, Althani renklood ja Edinburgi ploom. Häid tulemusi annavad ka Varajane punane, Späthi varajane, Roheline renklood ja Wangenheimi säilisploom, kuid nende õitseajad ei lange Liivi kollase munaploomiga ühte.

3. Varajasel sinisel on paremateks isasortideks Edinburgi ploom, Emma Leppermann ja Althani renklood.

4. Edinburgi ploomi headeks isasortideks on Wilhelmine Späth, Varajane sinine ja Emma Leppermann.

5. Wangenheimi säilisploomil on suur kalduvus isefertiilsusele. Paremateks tolmlejateks on Althani renklood ja Edinburgi ploom.

6. Oullinsi renkloodi jaoks osutuvad paremateks tolmlejateks Varajane sinine ja Edinburgi ploom.

7. Althani renkloodile on parimaiks tolmlejaiks Wangenheimi säilisploom ja Roheline renklood. Hăid tulemusi saadakse ka Edinburgi ploomi ja Späthi varajasega, kuid nende õitseajad sagedasti ei ühtu.

8. Wilhelmine Späthi tuleks arvestada kui praktiliselt isesteriilset sorti, millele paremateks tolmlejateks osutuvad Varajane sinine ja Emma Leppermann. Avaldab heades kasvutingimustes kalduvust isefertiilsusele.

9. Suure punase munaploomi jaoks on paremateks tolmlejateks Varajane punane ja Späthi varajane. Häid tulemusi annab ka Althani renklood.

10. Suure rohelise renkloodi jaoks on paremateks tolmlejateks Varajane sinine ja Edinburgi ploom.

11. Ruth Gerstetteri jaoks on paremateks tolmlejateks Varajane sinine, Emma Leppermann ja Wilhelmine Späth.

12. Suurele kollasele munaploomile on paremateks tolmlejateks Varajane sinine, Emma Leppermann ja Wilhelmine Späth.

\section{Kunstlikel tolmutamistel külgejäänud viljade ja sahharoosi lahuses idanenud tolmuterade vahekorrast}

Sortide vastastikuse tolmlemise küsimuse lahendamisel tuli ka kindlaks teha kas sahharoosi lahuses idanenud tolmuterade idanemisprotsendi ja kunstlikel tolmlemiskatsetel külgejäänud noorte normaalselt arenenud viljade arvu vahel on valitsemas mingisugust kindlamat vahekorda, s. o. kas 
sordid, millel sahharoosi lahuses on kõrgem idanemisprotsent, osutuvad ka paremaiks tolmlejaiks kui madalama idanemisprotsendiga sordid. Nimetatud küsimuste kohta on paljude uurijate arvamused lahkuminevad ja paljud uurijad ongi laboratoorsete uurimistega püüdnud tolmuterade idanemise protsendi alusel kindlaks määrata paremaid tolmlejaid isasorte. Olevaate saamiseks meie uurimistulemustest on tabelis toodud emasordi kolme aastane keskmine normaalselt arenenud külgejäänud noorte viljade arv kolme eri isasordiga, milledega kunstlikel tolmlemistel on saadud paremaid tulemusi. Samuti on toodud andmed nimetatud isasortide tolmuterade idanemise kohta, mis on saadud optimaalses sahharoosi lahuse kontsentratsioonis.

Tabel 6

Tolmuterade idanemise ja külgejäänud viljade vahekord

\begin{tabular}{|c|c|c|c|}
\hline Emasort & Isasort & $\begin{array}{c}\text { Normaalselt arenenud } \\
\text { noorte viljade keskmine } \\
\text { arv }\end{array}$ & $\begin{array}{l}\text { Tolmuterade idanemise } \\
\text { keskmine } \% \text { isasordil }\end{array}$ \\
\hline \multirow[t]{2}{*}{ Antonovka } & Seerinka & 67,4 & 85,1 \\
\hline & $\begin{array}{l}\text { Liivi sibulöun } \\
\text { Kollane Richard }\end{array}$ & $\begin{array}{l}65,0 \\
46,4\end{array}$ & $\begin{array}{l}92,1 \\
81,2\end{array}$ \\
\hline \multirow[t]{2}{*}{ Borovinka } & Valge Astrahan & $\begin{array}{l}40,4 \\
58,1\end{array}$ & $\begin{array}{l}81,2 \\
93,1\end{array}$ \\
\hline & $\begin{array}{l}\text { Liivi sibulōun } \\
\text { Antonovka }\end{array}$ & $\begin{array}{l}56,5 \\
54,8\end{array}$ & $\begin{array}{l}92,1 \\
66,4\end{array}$ \\
\hline \multirow[t]{2}{*}{ Tšernogus } & Leedu pepin & 39,9 & 45,4 \\
\hline & Pärnu tuviōun & 39,8 & 83,2 \\
\hline \multirow[t]{2}{*}{ Filippa } & $\begin{array}{l}\text { Lifivi sibuloun } \\
\text { Antonovka }\end{array}$ & $\begin{array}{l}33,5 \\
54,7\end{array}$ & $\begin{array}{l}92,1 \\
66,4\end{array}$ \\
\hline & Liivi sibulōun & 46,4 & $\begin{array}{l}00,4 \\
92,1\end{array}$ \\
\hline \multirow{3}{*}{ Leedu pepin } & Borovinka & 24,6 & 80,6 \\
\hline & $\begin{array}{l}\text { Liivi sibulōun } \\
\text { Pärnu tuviōun }\end{array}$ & $\begin{array}{l}66,9 \\
61,9\end{array}$ & $\begin{array}{l}92,1 \\
83,2\end{array}$ \\
\hline & Antonovka & 60,6 & 66,4 \\
\hline \multirow[t]{2}{*}{ Liivi sibulõun } & Antonovka & 61,1 & 66,4 \\
\hline & Aport & $\begin{array}{l}57,0 \\
55,1\end{array}$ & $\begin{array}{l}86,5 \\
85,1\end{array}$ \\
\hline \multirow[t]{3}{*}{ Seerinka } & Sügisjoonik & 52,8 & 80,0 \\
\hline & Liivi sibulöun & 37,8 & 92,1 \\
\hline & Pårnu tuviōun & 33,1 & 83,2 \\
\hline \multirow[t]{2}{*}{ Suislepp } & Valge klaarōun & $\begin{array}{l}47,8 \\
40 ?\end{array}$ & 84,5 \\
\hline & Liivi sibulōun & $\begin{array}{l}40,1 \\
25,0\end{array}$ & $\begin{array}{l}00,1 \\
92,1\end{array}$ \\
\hline \multirow[t]{3}{*}{ Pärnu tuviōun } & Tšernogus & 56,9 & 83,3 \\
\hline & Antonovka & 50,6 & 66,4 \\
\hline & Sügisjoonik & 35,0 & 80,0 \\
\hline \multirow{2}{*}{ Valge klaarôun } & $\begin{array}{l}\text { Suislepp } \\
\text { Vaarikôun }\end{array}$ & $\begin{array}{l}36,7 \\
33,3\end{array}$ & $\begin{array}{l}86,2 \\
69,0\end{array}$ \\
\hline & Leedu pepin & 33,0 & 45,4 \\
\hline
\end{tabular}

Toodud tabelist nähtub, et pole olemas kindlat paralleelsust tolmuterade idanemisprotsendi ja kunstlikel tolmlemistel külgejäänud noorte viljade arvu vahel. Sageli annavad isasordid, millel on madalam tolmuterade idanemisprotsent, kunstlikel tolmlemistel paremaid tulemusi kui kõrgema tolmuterade idanemisprotsendiga sordid. Seega ei võimalda sortide tolmuterade idanemiskatsed sahharoosi lahuses selgitada sortide vastastikuse tolmlemise küsimust. Keskmiselt ja hästi idanevate tolmuteradega sortidel on idanemisprotsent $30-100$. Sahharoosi lahustes tolmuterade idanemisega on vōimalik välja selgitada öige madala tolmuterade idanemise protsendiga sorte (idanemisprotsent $0-30$ ) kui viimaste tolmuterade steriilsus ei ole tingitud toitmisfüsioloogilistest pōhjustest. Tavaliselt madala tolmuterade idanemisega (idanemisprotsent $0-30$ ) sordid on osutunud ka halbadeks viljastajateks isa- 
sortideks, nagu seda tõestavad katsed sordiga Punane sügiskalvill, millel on ka väga madal idanemisprotsent $(27,7)$, mis ei olnud tingitud toitmisfüsioloogilistest tingimustest.

Katsete tulemustest selgub ka, et sordid, milledel on madal idanemisprotsent ja mis seepärast peaks kuuluma halvemate tolmlejate hulka, ei ole sugugi veel igakord halvad emasordid. Oites, milledes isased ō:eosad on puudulikult arenenud, võivad emased õieosad olla täiesti elujõulised, mis on vastupidine Kobeli vaatele, kes oletas, et puudulikult arenenud isaste õite osadele vastavad samasuguselt arenenud emased ōieosad. Seda näeme selgesti Leedu pepini juures, sest oma madala tolmlemise idanemisprotsendi $(45 \%)$ tōttu kuulub ta halvemate idanejate hulka, kuid Leedu pepinit emasordina kasutades osutub ta paremaks, andes võōra sortide õietolmuga mōnedel aastatel tolmeldes rohkem noori vilju kui ükski teine sort.

\section{Oksikute isasortide tolmu mõjust emasordi vilja lihale}

Katsetulemused näitasid, et noorte viljade edaspidine arenemine oleneb mitte niivőrd viljastatud seemnepungade arvust kui toitmistingimustest, mis

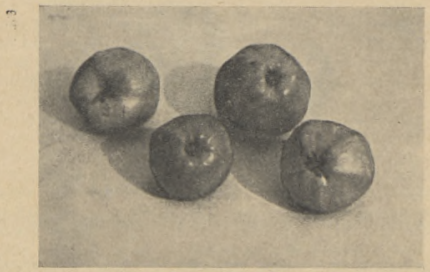

Foto 1. Emasort Antonovka kunstlikult tolmelduna järgmiste isasortidega: Liivi sibulōun, Seerinka, Tallinna pirnôun, Wealthy, Valge klaarōun.

juba alguses viljastamisel luuakse ühe või teise isasordi tolmuga. Selgusele jõudmiseks eri isasortide tolmu mōjust emasordi vilja lihale korraldati vastavad katsed Antonovkaga.

Antonovkal kastreeriti 100 õit ja neid tolmeldi kunstlikult, nii, et iga emakaarmi harule kanti eri isasordi tolmu, kusjuures kolm isasorti valiti säärased, mis kunstlikel tolmlemistel andsid Antonovkaga häid tulemusi (Liivi sibulõun, Seerinka ja Wealthy) kuna kaheks isasordiks (Valge klaaroun ja Tallinna pirnõun) valiti just säärased, mis ei andnud kunstlikel tolmlemistel soovitud tulemusi.

100 kastreeritud Antonovka oit tolmeldi ainult ühe sordi ōietolmuga (Valge klaarõun) mis kunstlikel tolmlemistel ei andnud soovitud tulemusi.

Sügisel võib viljade valmimisel märgata, nagu ilmneb ka juuresolevatest fotodest, et neist õitest, mille emaka iga haru tolmeldi eri sordi tolmuga, arenesid viljad, milledel vilja kandid olid välja kujunenud väga ebaühtlaselt. Oitest, mida tolmeldi ainult ühe isasordi tolmuga, kujunesid kaunis ühtlaste kantidega viljad.

Kuigi ei olnud võimalik jälgida, millise seemnepunga suudmele teatud isasordi tolmutoru tungis ja millise munarakuga tütartuum, mis tekkis tol- 
mutorus olevast generatiivsest tuumast, ühines, vōib siiski toodud katsete tulemustest järeldada, et eri isasortidega viljastatud seemnepungades tekib vastavalt nôrgem vôi tugevam toitainete juurdevool, mis seemne läheduses olevad viljakandid nōrgemalt vōi tugevamalt välja kujundab.

Selgema ülevaate saamiseks kuidas üksikute isasortide tolmuga viljastamine mõjub emasordi viljalihale, korraldati vastavad katsed sortide Filippa ja Leedu pepiniga, viles nende juures läbi kunstlikud tolmlemised kolme isasordiga, kusjuures isasortideks valiti säärased, mis kolme aasta kunstlike tolmlemiskatsete tulemuste pôhjal osutusid eelpoolnimetatud emasortidele headeks tolmlejaiks, kui ka sääraseid sorte, mis kunstlikel tolmlemiskatsetel andsid mittesoovitavaid tulemusi, s. o. kus külgejäänud viljade protsent oli väike. Igast ristluskombinatsioonist tolmeldi 200 kastreeritud õit, kusjuures õied valiti võrdse asendiga okstel, samuti arvestati ka ōie asukohaga okstel, et noorele arenevale viljale luua vōrdseid arenemistingi-

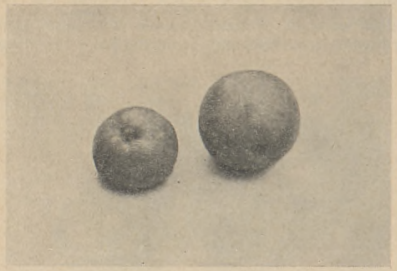

Foto 2. Emasort Antonovka kunstlikult tolmelduna isasordiga Valge klaarôun.

musi. Igast ristluskombinatsioonist mõõdeti 30 vilja, välja arvatud Leedu pepini ja Suislepa õuna kombinatsioon. Kus külgejäănud noorte viljade arv osutus vähemaarvuliseks, seal oli võimalik mõôtmisi teostada 11 vilja juures. Mõõtmistega alustati 8 . juunil, sest mainitud ajajärgus oli suurem noorte viljade varisemise järk lõppenud ja külgejäänud vilja võis vaadelda normaalselt arenenuna.

Peale viljade mõōtmist määrati nende juures kindlaks ka seemnete arv viljas, et jōuda selgusele, kuivõrd on emasordi liha juurdekasv olenev seemnete arvust (tabel 7 ).

Toodud tabelisto selgub, et mõlematel emasortidel on noorte viljade läbimõöt suurem nende isasortidega, milledega kunstlikel tolmlemistel kolmeaastase keskmine külgejäänud noorte viljade protsent on kõrgem. Kuigi mõõdetud viljade vahed üksikute ristluskombinatsioonide puhul on väikesed, on nad täpse mõōtmise juures siiski märgatavad.

Kui võrrelda viljades sisaldavate seemnete arvu ja viljade läbimōōtu, siis näeme, et siin ei ole valitsemas mingisugust kindlat vahekorda. Suurema läbimỗođuga viljad ei sisalda rohkem seemneid ning vilja läbimõõdu suurus ei ole viimastest tingitud.

Milliseid muutusi üksikute isasortide tolm kutsub esile vilja kujus, värvuses, erikaalus, säilivuses, keemilises koosseisus, milledele paljud uurijad, näit. Paškevitš $\left({ }^{2}\right)$ ja $\operatorname{Ro}\left({ }^{4}\right)$, on tähelepanu juhtinud, ei ole käesolevas töös jälgitud. 


\begin{tabular}{|c|c|c|c|c|c|c|c|}
\hline Emasort & Nr. & Isasort & Nr. & $\begin{array}{l}\text { Kolme aasta keskm. } \\
\text { kailgejalanud noorte } \\
\text { viljade } \%\end{array}$ & 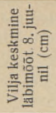 & 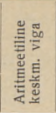 & 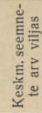 \\
\hline \multirow{4}{*}{$\begin{array}{l}\text { Filippa } \\
\text { Leedu pepin }\end{array}$} & \multirow{4}{*}{289} & \multirow{4}{*}{$\begin{array}{l}\text { Antonovka } \\
\text { Borovinka } \\
\text { Valge klaar- } \\
\text { ôun } \\
\text { Liivi sibul- } \\
\text { õun } \\
\text { Pärnu tuvi- } \\
\text { õun } \\
\text { Suislepp }\end{array}$} & $\begin{array}{l}294 \\
297\end{array}$ & $\begin{array}{l}56,2 \\
21,1\end{array}$ & $\begin{array}{l}3,23 \\
2,90\end{array}$ & $\begin{array}{l} \pm 0,19 \\
\pm 0,09\end{array}$ & $\begin{array}{r}8,2 \\
-7,5\end{array}$ \\
\hline & & & 293 & 22,6 & 2,97 & $\pm 0,21$ & 8,9 \\
\hline & & & 298 & 68,1 & 3,20 & $\pm 0,20$ & 8,5 \\
\hline & & & $\begin{array}{l}52 \\
86\end{array}$ & $\begin{array}{l}61,9 \\
48,8\end{array}$ & $\begin{array}{l}3,01 \\
2,98\end{array}$ & $\begin{array}{l} \pm 0,32 \\
\pm 0,19\end{array}$ & $\begin{array}{l}9,1 \\
8,0\end{array}$ \\
\hline
\end{tabular}

\section{Viljapuusortide õitseaegadest ja tolmlemisküsimustest.}

Kunstlike tolmlemiskatsete kokkuvõtte tulemustest võime näha, et sordid vastastikku tolmeldes ei anna võrdseid tulemusi. Uhed neist osutuvad paremaiks tolmlejaiks kui teised.

Uute suuremate kolhooside ja sovhooside puuviljaaedade rajamisel, mis toimub piiratud arvu sortidega, on väga oluline, et sinna paigutatakse sordid, mis üksteist viljastavad, kindlustades seega rikkaliku saagi.

Peale vastastikuse tolmlemise sortide vahel on suure tähtsusega ka nende õitseaegade ühtelangemine. Uksikute sortide õitseaeg on teatud määral kõikuv ning oleneb väga mitmesugustest teguritest. Juba tuulte eest kaitstud koht vōib ōitsemise mōne päeva vōrra varemini esile kutsuda. Kuivōrd tuulte eest kaitstud koht mõjub õite varajasemale puhkemisele, selleks teostati vastavaid uurimusi õunasortide Borovinka, Liivi sibulōuna ja Leedu pepini juures, kus selgus, et nimetatud sortidel avanesid õied kaitstud kohal kolme päeva võrra varem ja õitsemine jōudis siin ka varem lōpule. Peale tuulte eest kaitstud koha avaldab ôite puhkemisele mōju mullastik ja pōhjavee seis. Kergematel ja soojematel muldadel algab öitsemine kevadel hoopis varem kui raskematel külmadel muldadel, kus pōhjavee seis on kōrge. Samuti avaldab öitseaegadele mōju ka alus, millele on poogitud kultuursort ja vōras toimuvad kärpimised, mis mōjuvad ōitsemisele pikendavalt.

Uldiselt mõjub õitseaja kestusele kõige enam temperatuur, pikendades vôi lühendades õitseaega. Hiliste kevadiste külmade tōttu pidurdub sageli õitsemine, ning järsu temperatuuri tõusuga, kui pole takistuseks suuremaid sademeid, avanevad ōied kiiresti. Oitseaeg on lühike ja tolmlemine kiire, sest soodsa ilmastiku tõttu on mesilaste tegevus intensiivne ning tolm kantakse õielt öiele. Samuti pole üksikute sortide öitseaja alguste vahel märgata suuremaid vahesid.

Mönel kevadel algab õitsemine kaunis varakult, kuid järgnevate vilude ja niiskete ilmade tõttu toimub öite puhkemine väga visalt ja järkude kaupa. Oitseaeg venib pikale ja selgesti ilmneb vahe üksikute sortide õitseaegade vahel.

Kolmeaastased tulemused uuritud õuna- ja pirnisortide juures näitasid, et kuigi üksikutel sortidel õitsemise algus on veidi erinev, langeb õitseaeg mõneks päevaks siiski kokku, mis võimaldab teostada tolmlemist. Teine olukord valitseb Eesti NSV-s levinud ploomi- ja kirsisortide juures, kus üksikud sordid on oma õitseaegadelt erinevad. Olgugi et nad kunstlikul tolmle- 
misel annavad häid tulemusi, ei sobi nad siiski tolmuandjateks isasortideks, sest tolmuandja isasordi ơitsemisaeg peab enam-vähem kokku langema emasordi öitseajaga. Nimetatud asjaoluga ongi arvestatud artikli eelnenud osas, mis käsitles paremate tolmlejate valikut ploomide ja kirsside juures.

Tolmlemise kordaminekuks on väga mōõduandvad ka meteoroloogilised elemendid ja esmajoones tuleks siin nimetada temperatuuri. Kōrge temperatuur ja kuiv õhk õitseajal mōjub tolmlemise kordaminekule pidurdavalt. Kōrge temperatuuri ja kuiva ōhu puhul kuivab emaka suudmest erituv vedelik ja ta kontsentreerub niivõrd, et tolmutera enam seal ei idane. Samuti võib kổrge temperatuur ja kuiv õhk õitsemise ajal esile kutsuda teatud degenereerumisprotsessi sugurakkudes. Halvavalt mōjub tolmlemise kordaminekule ka madal temperatuur, mis kevadel tavaliselt on ühenduses vihmasadude ja uduga. Pikaajalised vihmasajud uhuvad tolmukotikestest välja tolmuterad, või tihti hävinevad viimased. Tolmuterad, sattudes niiskesse keskkonda, hakkavad eristama teatud sekreeti, kui aga mingisuguste tegurite tagajärjel idanemine ei saa toimuda, siis on sekreedi eritamine niivorrd rohke, et hiljem osutub idanemine vöimatuks, sest biokeemilist tasakaalu, mida tolmutera idanemiseks vajab, ei ole vōimalik enam uuesti jalule seada. Pikemaajalistel vihmasadudel võimegi õitsemise ajal ja igal pool näha pruune tolmuterasid, milline värv on tingitud peamiselt sellest, et tolmuterade eristuvas sekreedis on fosfatiide, mis vees lahustuvad ja mis ōhuhapnikuga kokku puutudes muutuvad pruuniks. Samuti mōjuvad pikemaajalised vihmasajud õitsemisajal halvavalt ka emakaarmile, pestes emakaarmilt eristuva vedeliku, mis teatud juhtudel võib emakakaela kaastegevusel siiski uuesti tekkida. Oldiselt peab märkima, et pikemaajalised sademed oitsemisajal, mis toovad endaga kaasa ka temperatuuri languse, mōjuvad halvasti tolmlemise kordaminekule. Sademeterikkail madalama temperatuu. riga ōitseaegadel on ka mesilaste tegevus väga piiratud.

Suuremate kolhooside ja sovhooside aedade rajamisel, mis toimub piratud arvu sortidega, tuleb pōhjalikult kaaluda üksikute liikide ja sortide paigutamist kvartalitel, kusjuures tööde ratsionaliseerimise mõttes on tarvilik. ônapuudel paigutada tali-, sügis- ja suvisortide rühmad kvartalitele eraldi, kuna nende segístutamine valmistaks töö korraldamisel palju raskusi ja lisakulutusi. Sortide paigutamisel erikvartalitele tuleb tôsiselt arvestada sortide vastastikust tolmlemisvajadust. Tegelikud tähelepanekud ja katsetulemused on näidanud, et vahekaugus viljastatava ja tolmuandja sordi vahel ei tohiks ületada $50-60$ meetrit. Suuremate vahekauguste korral hakkab saak juba tunduvalt langema. Eriti on see märgatav siis kui kevadisel öitsemise ajal on ilmastik vihmane ja tuuline, millal mesilased teevad vaid lühikesi lennuringe.

Sortide paigutamisel kolhooside ja sovhooside aedadesse vôib kasutada vastastikuse tolmlemise soodustamiseks väga mitmeid viise, millest allpool on toodud rohkem tarvitusel olevad: 1) kui viljastatav ja tolmuandja sort on võrdse majandusliku väärtusega standardsordid, tuleks nad istutada vaheldumisi $6-7$ rea kaupa, näit. 6 rida Antonovkat ja 6 rida Tartu roosõuna jne. vôi 3 rida Antonovkat ja 3 rida Tartu roosõuna; 2) juhul kui tolmuandja sort on väiksema majandusliku väärtusega, tuleks viljastatavaid kōrgema väärtusega sorte istutada $4-6$ rida, millele järgneks $2-3$ rida tolmuandjaid sorte.

Uksikute tolmuandjate viljapuude vaheleistutamine teise sordi ridadesse ei ole soovitav, sest see raskendab tunduvalt töö korraldamist suuremais puuviljaaedades.

Pirnipuude, ploomipuude ja kirsipuude osatähtsus on suurtes kolhooside ja sovhooside puuviljaaedades tunduvalt väiksem kui õunapuudel, kuid ka 
siin tuleb neid aia planeerimisel paigutada erikvartalitele ja sortide paigutamisel tõsiselt arvestada nende vastastikuse tolmlemisega.

Kuna mesilased, nagu juba eelpool mainitud, on viljapuude vastastikusel tolmlemisel kõige tähtsamad tolmuülekandjad, siis on sortide vastastikuse tolmlemise heaks kordaminekuks vajalik, et suuremate kolhooside ja sovhooside puuviljaaedades oleks õitsemise ajal vähemalt 2 mesilasperet ühe hektari puuviljaaia kohta, ja et mesilaspered oleks õitsemisajal ühtlaselṭ paigutatud kogu aias.

Eesti NSV Teaduste Akadeemia

Taimekasvatuse Institunt

Saabus toimetusse

9. V 1953

\title{
KIRJANDUS - ЛИTEPATYPA
}

1. И, В. М н чу рин, Сочинення, Том I и II, Москва, 1948.

2. В. В. П ашкевич, Материалы к вопросу о влиянии собственной и посторонней пыльщы разных сортов яблонь на завязывание плодов. Труды по прнкладной ботаннке и селекции $1924-25 \mathrm{rT}$.

3. И. Н. Р я 6 ов, Вопросы опылення и плодоношения плодовых деревьев, Ялта, 1930.

4. Л. М. Р о, Матерналы по изучению влияния опылителей на развитие плодов и семян у опыляемых сортов. Труды Илнвской садово-огородной опытной станщин, 1929.

5. Н. В. Т у р 6 ин, Успехи современной биологии. Выпуск $2(5), 1952$.

6. T. D. Lõs senko. Agrobioloogia, Tartu 1949.

7. A. M, S $1 \mathrm{imon}$. Tolmuterade fussioloogilised uurimused Eesti enamlevinenud ōunapuu sortidel, Tallinn 1937.

\section{ИССЛЕДОВАНИЕ ВЗАИМНОГО ОПЫЛЕНИЯ РАСПРОСТРАНЕН- НЫХ В ЭСТОНСКОИ ССР СОРТОВ ПЛОДОВЫХ КУЛЬТУР}

\author{
А. М. Сиимон, \\ доктор сельскохозяйственных наук
}

Резюме

Исследование взаимного опыления распространенных в Эстонской ССР сортов плодовых культур было проведено в 1945-1952 гг. на экспериментальной базе сектора садоводства Института растениеводства АН ЭССР в филиале Полли. Работами по изучению взаимного опыления было охвачено 26 сортов яблони, 6 - груши, 9 - вишни и 13 сортов сливы.

Подытоживая результаты опытов по искусственному перекрестному опылению сортов яблони, можно отметить, что почти самостерильными оказались сорта Пепин литовский, Кальвиль красный осенний, Суйслеп, Бойкен, Снгне Тиллиш, Грушовка таллинская и Титовка; практически самостерильными оказались сорта Целлини, Фэймез, Филиппа, Кронсельское прозрачное, Голубок Крюгера, Кортланд, Лифляндское луковичное, Пайдеское зимнее, Пыльтсамаское зимнее, Осеннее полосатое, Черногуз, Малиновка, Папировка и Уэлси; почти самостерильными являются сорта Антоновка, Боровинка, Земляничное Ничпера, Пярнуский голубок, Серинка; склонность к партенокарпии имеется у сортов Целлини, Сигне Тиллиш.

Из сортов груши оказались почти самостерильными Бере зеленая лифляндская, Лесная красавища; практически самостерильными - Бере Лутса, Бессемянка, Летняя Магдалина, Санитарный советник. 
Большинство распространенных в Эстонской ССР сортов вишни и сливы самостерильны или практически самостерильны и для обеспечения урожая нуждаются в опылении пыльцой другого сорта.

У цветка с плохо развитыми мужскими органами могут быть хорошо развиты женские органы цветка и при опылении чужой пыльцой такие сорта могут оказаться хорошими материнскими сортами, как это выяснилось в отношении Пепнна литовского.

Преждевременное опадение завязей не находится в зависимости от числа оплодотворенных семяпочек.

При искусственном опылении более распространенных сортов яблони выяснилось, что при опылении собственной пыльцой у плодов данного сорта уменьшилось количество нормально развитых семян и увеличилось количество щуплых.

Влияние пылыцы различных сортов-опылителей на развитие мякоти плода материнского сорта различно, причем прирост мякоти больше под влиянием пыльцы тех сортов-опылителей, от пыльцы которых при искусственном опылении у материнских сортов процент завязавшихся плодов выше.

Количество проросшей в растворе сахарозы пыльцы для сортов с высоким и средним процентом проросшей пыльцы не может характеризовать сорт как опылитель, так как сорта с высоким процентом проросшей пыльцы не для всех сортов являются лучшими опылителями. Степень прорастания пыльцы в растворе сахарозы может содействовать выявлению сортов с очень низким процентом проросшей пыльцы $(0-30 \%)$, которые одновременно являются и плохими опылителями.

Институт растениеводства Академии наук Эстонской ССР
Поступнла в редакцню 9 V 1953 